\title{
Theoretical and Empirical Review of Ethiopian Water Resource Potentials, Challenges and Future Development Opportunities
}

\section{Dessalegn Worku Ayalew*}

Faculty of Agriculture, Department of Soil and Water Resources Management, Woldia University, Ethiopia

*Corresponding author: Dessalegn Worku Ayalew, Faculty of Agriculture, Department of Soil and Water Resources Management, Woldia University, Woldia, P.O. Box: 400, Ethiopia, Tel: +987153344849; E-mail: desuworku60@gmail.com

Received date: July 28, 2018; Accepted date: August 15, 2018; Published date: August 22, 2018

Copyright: ( 2018 Ayalew DW. This is an open access article distributed under the terms of the Creative Commons Attribution License, which permits unrestricted use, distribution and reproduction in any medium, provided the original author and source are credited.

\begin{abstract}
Ethiopia is endowed with plentiful amounts of water resources potential. However, the backbone of Ethiopian economy, Agriculture, is highly rainfall dependent and the energy source relays on fuel wood. Even though the country has enough amounts of water resources potential, clear current figure of water resources potential especially in ground water part, utilization constraints and future water resources utilization opportunities is not clearly known. Reviews of different secondary data from various sources were conducted to fill these gaps. Based on the findings, The country has sufficient amount of surface water resources potential which is around 124 billion cubic meter and 30 million cubic meter (some but insufficient evidences shows it reaches 40 cubic meter) of ground water. The hydro power generation potential of major Rivers and Rift valley lakes is estimated to reach about 160,000 Megawatt/year. Irregular place to place and time to time sharing of major rivers and rain fall, cross boundary nature, topographic features of the country, technical and financial challenges are among main utilization constraints. The region has eye opening bright outlooks to go further in water resources development and utilization. Different factors hinder the utilization of the country water resources but these plenty amounts of water resource shows bright future opportunities to use it.
\end{abstract}

Keywords: Surface water; Groundwater; Water resource potentials; Hydropower

\begin{abstract}
Abbreviations and Acronyms: GWH: Megawatt; MoWE: Minester of Water and Energy; TWH: Terawatt; Ha: Hectare; MoFED Minister of Food and Energy Development; MW: Mega Watt; FAO: Food and Agricultural Organization; MASL: Meter above Sea Level
\end{abstract}

\section{Introduction}

Ethiopia is categorized under the first largest counties in the continent, in second range in population from Sub African countries and the income of the people is very low. It is dependent on agriculture which in turn subject to rainfall. The country current intention in the policy and strategy is supporting to apply household level small scale artificial water application [1].

The country has twelve River basins; Eight River basins namely Abay, Awash, Baro-Akobo, Genale-Dawa, Mereb, Omo-Gibe, Tekeze, Wabishebbele have water flow. One of them is lake basin called Rift valley and the remaining are dry basins which includes Aysha, Dinakle, Ogaden with no or insignificant flow out of the drainage system [2]. The country has also 12 major lakes which have enough potential to use for different purposes [3]. In addition, there is sufficient amount of underground water resources.

Factors lead to less use and development of water resources includes

- High temporal and spatial variability

- Most major Rivers are terminated to neighboring countries, around $97 \%$ of total flow
- The government gives priority to other sectors

- Lack of technical expertise to support the development

- Absence of well leadership in water subdivision.

- Spatially and temporally not equally distribution of those water resources. Ethiopia has varies future opportunity to develop water resources utilization [4].

The review shows the water resources potential of the country for irrigation and hydropower production as well as development challenges and future opportunities in the clearest way both theoretically and empirically but previously there were not wellorganized paper.

Safe drinking water supply and sanitation services of Ethiopia also found in lower rank in the world. More than half of the people are not access sanitation service and only around $60 \%$ access safe drinking water. The remaining is getting water together with animals from rivers, farm ponds reservoirs and other unclean water sources and use open defecation system. These accesses are also varying in rural and urban areas as well as it varies from state to state of the country. Urban areas are better in both safe drinking water access and sanitation service. So, the country is ranked lastly for access to safe human consumption water and sanitations services [5].

\section{Literature Review}

\section{Water resources potential and utilization in Ethiopia}

According to Ministry Of Water and Energy report, among the total area of land of Ethiopia the land area and water bodies are covered $99.3 \%$ and $0.7 \%$ respectively. Those water bodies are include major 12 river basins of the country; 8 Rivers with flow and one Rift valley with 
Page 2 of 7

water and the other 3 basins have not visible water flow due to they are located in the part of the country that is not get enough mount of rainfall throughout the year. There are also 12 major lakes, reservoirs and dams as well as sufficient amount of underground water sources. The amount of water obtained from the major River basins are estimated to reach more than 124.4 billion cubic meters (BCM). But all the River basins except Awash are transboundary Rivers in which 97 percent of flows terminate to neighboring countries.

\section{Surface water resources potential}

Major river basins: The good option to have to minimalize food shortage is access of water to farmer for irrigation and other uses [6]. Research findings indicate that insufficiently application of irrigation and rain fall dependent farming system as well as timely incremental distractions of nature gifted resources leads to progressive famine and low capital income of the people of the country [7]. The country water and energy office actively involved to increase the utilization capacity of these resource in the form of irrigation and around 500 irrigation sites which covers around 3.8 million hectare land is selected for irrigation.

The River basins of the country have varies properties in terms of yearly average discharge rate to its exits with different flow directions, terminals and also water sources. Those water accounts the large portion of water resources than other sources like ground water and other lakes and reservoirs. The country's surface water potential as identified and estimated by different authors to reach around 124 Billon $\mathrm{m}^{3}$ of water (Table 1), which is an indicator to have ample amount of water.

\begin{tabular}{|c|c|c|c|c|c|c|c|c|c|c|}
\hline \multirow{2}{*}{ No } & \multirow{2}{*}{$\begin{array}{l}\text { Name of } \\
\text { Basin }\end{array}$} & \multirow{2}{*}{ Type } & \multirow{2}{*}{$\begin{array}{l}\text { Altitude at source } \\
\text { (masl) }\end{array}$} & \multirow{2}{*}{$\begin{array}{l}\text { Altitude at Terminal } \\
\text { (Masl) }\end{array}$} & \multirow{2}{*}{$\begin{array}{l}\text { Area } \\
\left(\mathrm{Km}^{2}\right.\end{array}$} & \multicolumn{2}{|c|}{ Water resource } & $\begin{array}{l}\text { Hydro Power } \\
\text { Potential }\end{array}$ & $\begin{array}{l}\text { Percentage } \\
\text { Share }\end{array}$ & $\begin{array}{l}\text { Irrigation } \\
\text { Potential }\end{array}$ \\
\hline & & & & & & $\begin{array}{c}\text { Billion } \\
\mathbf{m}^{3}\end{array}$ & $\begin{array}{c}\text { Lt/sec/k } \\
\mathbf{m}^{2}\end{array}$ & \multicolumn{3}{|c|}{ (GWH/Year) of total (\%) in $\mathrm{Ha}$} \\
\hline 1 & Abay & River & 2000 & 500 & $1,99,912$ & 54.4 & 8.63 & 78,800 & 48.9 & $8,15,581$ \\
\hline 2 & Awash & River & 3000 & 250 & $1,10,000$ & 4.9 & 1.41 & 4,500 & 2,8 & $1,98,632$ \\
\hline 3 & Aysha & Dry & - & 400 & 2,223 & 0 & 0 & - & - & - \\
\hline 4 & Baro-Akobo & River & 3,000 & 395 & 75,912 & 23.23 & 9.7 & 18,900 & 11.7 & $10,19,523$ \\
\hline 5 & Dinakle & Dry & - & 160 & 64,380 & 0.86 & 0.42 & - & - & $1,58,776$ \\
\hline 6 & Genale Dawa & River & 4,300 & 180 & $1,72,259$ & 6 & 1.1 & 9,300 & 5.8 & $10,74,720$ \\
\hline 7 & Mereb & River & 2,500 & 900 & 77,120 & 0.72 & 3.87 & - & - & 5,000 \\
\hline 8 & Ogaden & Dry & - & 400 & 79,000 & 0 & 0 & - & - & - \\
\hline 9 & Omo-Gibe & River & 2,800 & 350 & 52,000 & 16.6 & 6.66 & 35,000 & 22.7 & 67,928 \\
\hline 10 & $\begin{array}{l}\text { Rift Valley } \\
\text { Lakes }\end{array}$ & Lake & 4,193 & 550 & 5,900 & 5.64 & 3.44 & 800 & 0.5 & $1,39,300$ \\
\hline 11 & Tekeze & River & 3,500 & 300 & 82,350 & 8.2 & 3.16 & 6,000 & 4.2 & 83,368 \\
\hline 12 & Wabishebele & River & 4 & 200 & $2,02,220$ & 3.4 & 0.53 & 5,400 & 3.4 & $2,37,905$ \\
\hline - & Total & - & - & - & - & 123.95 & & $1,59,300$ & & $38,00,733$ \\
\hline
\end{tabular}

Table 1: Major basins with its irrigation and hydropower potential [7-10].

The major water basins of the country have a large capacity to annual and perianal irrigation. Irrigation potential of major rivers and Rift Valley Lakes is estimated to reach around 3,800,733 hectare of land (Table 1).

From the total of estimated 650 million TWH hydropower production potential of the country in different sources, approximately 160 million TWH is from major rivers and Rift valley lakes. Even if the country has a huge hydropower generation capacity but highly dependent on fuel wood in the energy sector especially the rural parties of the country, to say totally depend on locally available resources like crop restudies, cow dungs corrosive like other less developed countries in the continent. As shown in the table and Graph bellow, only $1 \%$ is contributed from Hydropower from the total energy sources [8-11]. It is hopeful enough this figure is greater currently.
The less accessibility to hydropower for energy supply in different parts of the country and its implication in the development of the economic sector is well recognized by the government and are go a headed to overcome it. Numbers of hydropower infrastructures is ongoing in this time from different Rivers. The country uses a full potential to increase the hydropower current production which is $2,218 \mathrm{MW}$ to more that 10,000 after those huge power generating dams are become end of and operate. After the Grand Ethiopian Renaissance Dam which is constructed in Abay/Nile River that has a capacity to generate 6,000 MW, and the Gibe cascading dam's hydropower projects are fully operated the power production capacity of the country will move from currently 2,000 MW to 10,000 MW (Figure 1) [12].

According to the study result of Solomon, the hydropower production potential of Ethiopian river basins is estimated to reach around 159,300 MW per year (Table 1). 
Page 3 of 7

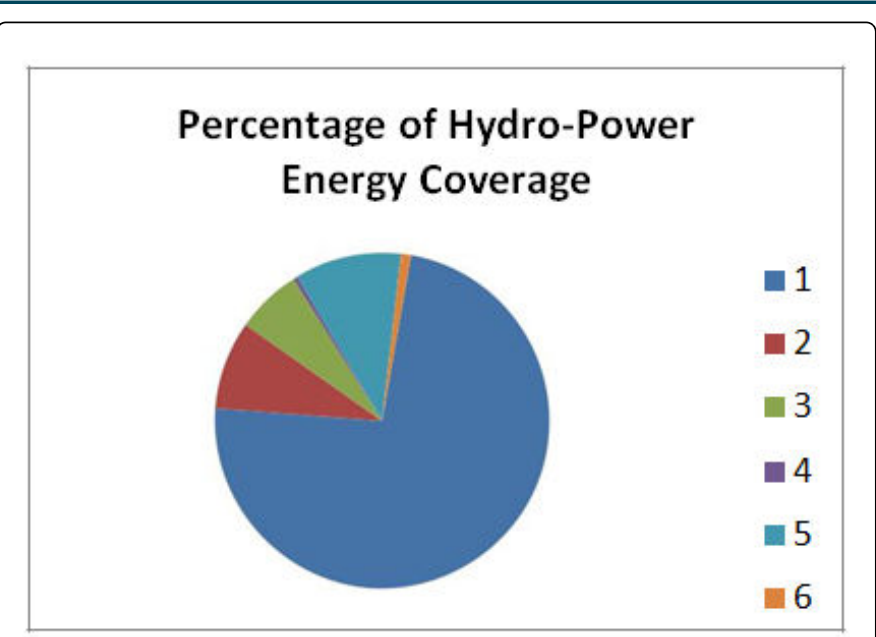

Figure 1: Percentage of hydropower energy coverage [11].

Major lakes in Ethiopia and their potential: Ethiopia also has sufficient amount of lacks which are distributed in different parts of the country especially in the central, south and south west areas. They store sufficient volume of water that can be used for different purpose. For instance, different studies show that 5.7 billion cubic meter water is stored and exposed to evaporation in the lakes, wetlands, and flood plains of the basin [8].

The country has 11 fresh and 9 saline lakes, 4 crates lakes and over 12 major swamps or wetlands. Most of lacks are located in one of the country river basin called rift valley. The depth of some lakes and reservoirs are not known yet, due to that is it difficult to estimate the total volume of water obtained from these lakes.

Ethiopia has 12 major lakes which cover about $7,300 \mathrm{~km}^{2}$ area and storage potential of about $84.79 \mathrm{BCM}$. Those lakes are located in different states of the country and they have different Elevation, drainage and surface, depth area as well as storage volume (Table 2).

\begin{tabular}{|c|c|c|c|c|c|}
\hline $\begin{array}{c}\text { Name of } \\
\text { Lake }\end{array}$ & $\begin{array}{c}\text { Elevation } \\
(\mathbf{m a s} \mathbf{)}\end{array}$ & $\begin{array}{c}\text { Drainage } \\
\text { area } \\
\mathbf{( K m}^{2} \mathbf{)}\end{array}$ & $\begin{array}{c}\text { Surface } \\
\text { area } \\
\mathbf{( K m}^{2} \mathbf{)}\end{array}$ & $\begin{array}{c}\text { Max.depth } \\
\mathbf{( m )}\end{array}$ & $\begin{array}{c}\text { Volume } \\
\mathbf{( B C M )}\end{array}$ \\
\hline Tana & 1,788 & 15,319 & 3,156 & 14 & 28.4 \\
\hline Ziway & 1,636 & 7,380 & 440 & 9 & 1 \\
\hline Langano & 1.585 & 2,000 & 230 & 46 & 3.8 \\
\hline Abijata & 1,580 & 10,740 & 180 & 14 & 1 \\
\hline Shala & 1,550 & 2,300 & 370 & 266 & 37 \\
\hline Awassa & 1,680 & 1,300 & 129 & 22 & 1 \\
\hline Abaya & 1,169 & 16,342 & 1,140 & 24.5 & 9.82 \\
\hline Chamo & 1,110 & 18,575 & 317 & 14.2 & 3.24 \\
\hline Chew Bahir & 570 & - & 1125 & - & - \\
\hline Hayq & 1,900 & 83 & 23 & 81.41 & 1.01 \\
\hline Ashenge & 2,440 & 129 & 140 & 25.5 & 0.25 \\
\hline Beseka & 1,900 & 420 & 48.5 & 7 & 0.28 \\
\hline & & Total & & & 84.79 \\
\hline
\end{tabular}

Table 2: Major lakes of Ethiopia [3, 13-18].

\section{Results and Discussion}

\section{Groundwater resources potential}

Assessment of ground water potential of the country has not a past history. It is started recently and after then different studies argue to each other on its potential. Due to less information about the ground water availability, it leads much difficult to have information about the water cycles, the amount of extraction and percolation in to the ground water to recharge it for the sake of the required water management techniques in the right place and time. To solve such type of a problem, the ground water database of the Ethiopian national was placed since 2013 and this institution is working together with minister of water of Ethiopia and lower level water resources development office, Non- governmental and private water work enterprise are working

Whatever a case, the ground water potential of the country is much lower than the surface water potential. However, most people of the country are found water from this underground water sources. From the total recharge of the groundwater in different systems, both natural and artificial, more than $50 \%$ of it is take out to use for domestic water use [6].

Different arguments were present on the ground water potential of the country. Detailed studies are conducting currently about the underground water prospective. It disproves the ground water usage is not the same amount which is described in the previous studies i.e., 2.6 $\mathrm{BMC}$. Current estimates indicate that the ground water budding is reached more than $30 \mathrm{BCM}$ if all ground water parts are assessed [19]. Ground water is highly influenced by different geophysical and climatic factors like geology, topography, and environmental conditions which makes difficult to obtained productive aquifer. Due to that the occurrence of ground water is not uniform everywhere [20].

\section{Water Resources Expansion Platform (WREP)}

WREP deals with water movement study called hydrology, weather forecasting on surface and ground water resources and preparation of integrated water- resources master plans for river basins. Activities such as excess overflow minimization and basin controlling are also set in this subdivision. The WREP provides a basis for the implementation of other sub-sectoral programs, in terms of data and information resources, execution of multipurpose projects, and technical services such as quality standards. In summary, it is an integrated discipline dedicated to optimizing the varied uses of country's water resources [21].

\section{Water resources expansion platform goals}

According to MoWR, the principal goal of the water resources expansion platform is to promote conditions for sustainable development and management of the region to secure fiscal growth and community welfares as well as environmental protection in a good manner [21]. Towards this goal, the WREP attempts to target on the succeeding objectives 
- Assess and develop the country's surface water and groundwater resources and promote optimal utilization for diverse uses

- Optimize use of water resources by focusing on multipurpose water-resources development

- Ensure appropriate watershed management practices to promote water conservation, maximize water yields, improve water quality and reduce reservoir siltation; Protect water resources from pollution through development.

With together its specific objectives, the WREP consists of the following six major components. A number of interventions are done under each component. The components include

- Water resources assessment

- Flood protection

- Master plans for integrated basin development

- Regional projects and

- Eastern Nile Cooperation Project

\section{Future opportunities for water resources development and utilization}

According to Awulachew report, Ethiopia has a great future opportunity to develop water resources and utilization. Among many opportunities, some of them are:

- Enough water sources potential

- The government of the country turn the face and focus on water resources development and utilization

- Different funders are promised to support the water sector development

- A probability to apply multipurpose use of those water resources like for irrigation and hydropower generation

- An opportunities to produce qualified expertise in different higher institutions to fill the gap of knowledge barrier and distributed throughout the country being expertise and train the low level expertise which works in different sectors in the form of training, experience sharing, give technical support if required

- The opportunity to gender mainstreaming in all levels of water development projects staring from the beginning of the project to the end of it.

\section{Challenges of water resources development and utilization}

As stated above, Ethiopia is endowed by sufficient amount surface and subsurface of water resources. Those water resources have enough potential for irrigation, domestic water supply, and fishery industry as well as hydropower generation. According to the report of Awulachew et al. MoWE and FAO, the irrigation prospective of those river basins we have is approximately $3,800,733$ hectare of land [8,9,13]. Among the total potential of 3.6 million hectares of irrigable potential land only $3-5 \%$ is supported by irrigation. The higher demand of the current generation is never satisfied without supporting by artificial application of water in the form of fully and supplementary artificial application of water.

The surface water resources mainly river basins, have the potential to produce 650 million TWH hydropower but, about 160 million TWH is technically and economically exploitable currently. Only $1 \%$ is contributed from Hydropower [11].
In addition to these, the country also has a huge among of water from lakes, reservoirs as well as ground water too. But when we look at the utilization, it is in infant stage in both agricultural and hydropower uses as we have seen above. The country is ranked lastly for access to safe human consumption water and sanitations services as well [5].

There are different factors for the above mentioned challenges. Those factors can group into four main categories. Those are natural factors of the water bodies; technical problem of the expertise; financial limitation and utilization of the nation, and weak governance in water sectors hinder the water sector development.

\section{Hydro politics challenges}

All of the major river basins except Awash are transboundary, originated from Ethiopia and flow to neighboring countries [2]. On the other hand, transboundary River management system is not properly implemented with the riparian countries. Due to this, the downstream countries are always complaining when the Ethiopian Government wants to construct the dam and other infrastructures to use it for different purposes. The current situation between Ethiopia and Egypt on the great renaissance Dam is a good example (Table 3).

\begin{tabular}{|c|c|c|c|c|}
\hline No & Basin Name & Orginated & Terminal & $\begin{array}{c}\text { Flow } \\
\text { Direction }\end{array}$ \\
\hline 1 & Abay & Ethiopia & Sudan Border & West (Nile) \\
\hline 2 & Awash & Ethiopia & Terminal Lakes & North east \\
\hline 3 & Aysha & Ethiopia & Djibouti Border & No flow \\
\hline 4 & Baro-Akobo & Ethiopia & Sudan Border & West (Nile) \\
\hline 5 & Dinakle & Ethiopia & Kobar Sink & No flow \\
\hline 6 & Genale Dawa & Ethiopia & Somalia Border & East \\
\hline 7 & Mereb & Ethiopia & Eritrean Border & West (Nile) \\
\hline 8 & Ogaden & Ethiopia & Somalia Border & No flow \\
\hline 9 & Omo-Gibe & Ethiopia & Rudolpha Lake & South ( Nile) \\
\hline 10 & Rift Valley Lakes & Ethiopia & Sudanese Border & South \\
\hline 11 & Tekeze & Ethiopia & Chew Bahir & West (Nile) \\
\hline 12 & Wabishebele & Ethiopia & Somalia Border & East \\
\hline
\end{tabular}

Table 3: Flow direction and terminal of major water rivers [2].

To develop water use projects for example dams on the transboundary Rivers obviously needs the willingness of all riparian countries, if not different financial funders are not voluntary to give loans for the construction and other purpose of that project as well as lead to demand conflict between common users. But most of water projects especially the one which needs higher capital cannot construct by the country budget due to our low per capital income. So, even if those Transboundary Rivers are originated from Ethiopia, big projects are not constructed yet since have the aforementioned causes and the riparian countries have a right to decide in share and have to get their willingness. In addition to that, there is not any clear legally based agreement on anyone of the River we have. Those causes hinder the construction of the projects that the country wants for different purposes for development and to satisfy social needs of the people of the country as well. The Nile River that is the big river which around 
Citation: Ayalew DW (2018) Theoretical and Empirical Review of Ethiopian Water Resource Potentials, Challenges and Future Development

78 percent of the total flowing water is originated from Ethiopia is highly sophisticated cause due to have many share countries.

\section{Uneven spatial and seasonal distribution of rainfall}

Ethiopia has a complex rain fall system. All parts of the country are not getting equally amount of rain fall. The north Eastern, East and south eastern parts of the country get less amount of rain fall. Due to that, the three river basins which are located in these parts namely Ogaden, Aysha and Dinakle are mostly dry. It has seasonal and annual inconsistency rainfall due to the result of multiple weather condition including Subtropical Jet, Inter-tropical Convergence Zone, Red Sea Convergence Zone, Tropical Easterly Jet, and Somali Jet (Figure 2) [22].

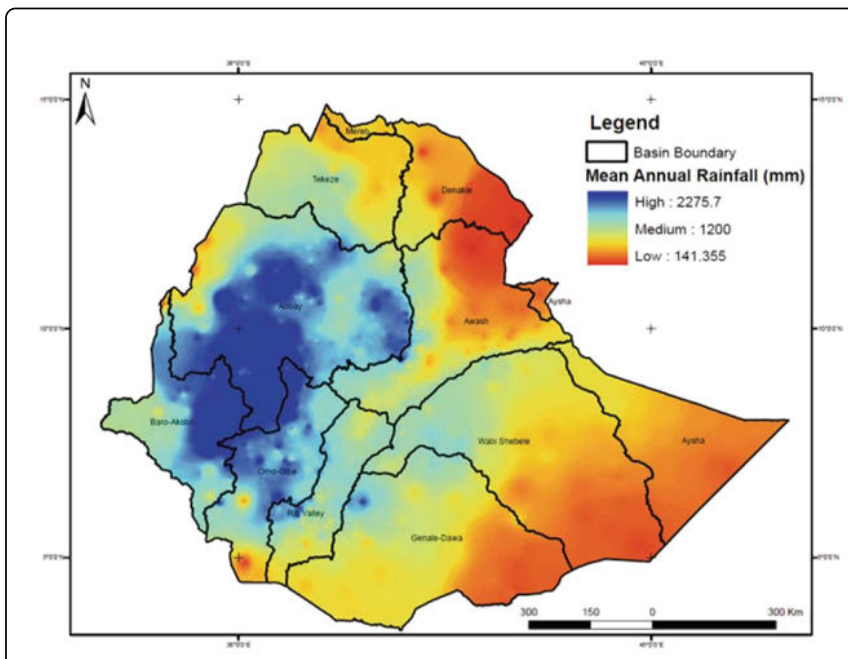

Figure 2: Uneven spatial distribution of rain fall [23-26].

\section{Uneven temporal and spatial distribution of major rivers}

Water resources in Ethiopia are highly governed for spatial and temporal variability. These spatial and temporal variability is due to the country has different climate, topography, soil, and geology conditions which deters the water sector development. Rain fall in Ethiopia, especially in arid and semi-arid regions, are highly subjected on temporal erraticism; in terms of seasonal distribution pattern, average mean amount. It is also highly lay open to on spatial variability; which means it becomes vary from place to place. Due to highly variability and insufficient rainfall of the country, the economic development is highly subjected to deterioration. The distribution of all rivers show that there is considerable variation of runoff in a year, and large flow occurs in the period of Mid June to Mid-October, where in most case no irrigation is needed except in erratic rainfall areas in the form of supplemental irrigation (Figure 3) [27].

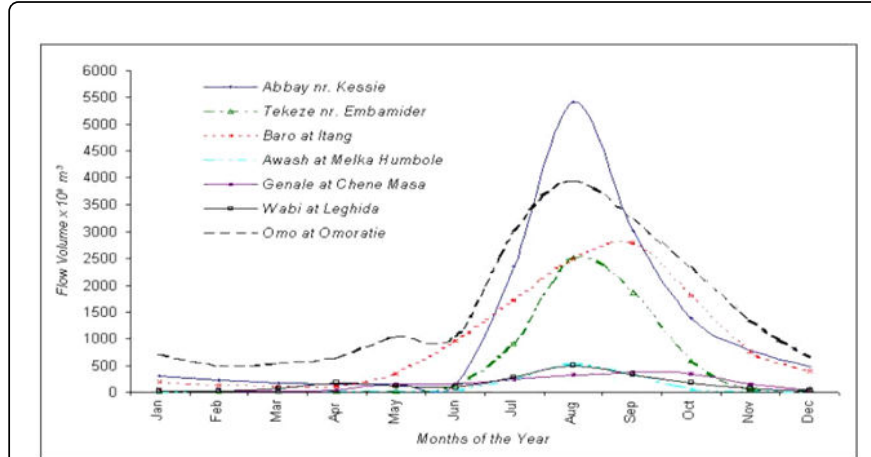

Figure 3: The water resources potential and variability of major rivers in Ethiopia.

Similarly, most of high flow potential major river (which occupies $80-90 \%$ flow) are found in the west and south west parts of the country but they support less than $40 \%$ of the country population whereas less than $20 \%$ flow of water is in the river basins found in East, south east, central and some parts of Northern region of the country which supports more than $60 \%$ population (Figure 4 ).

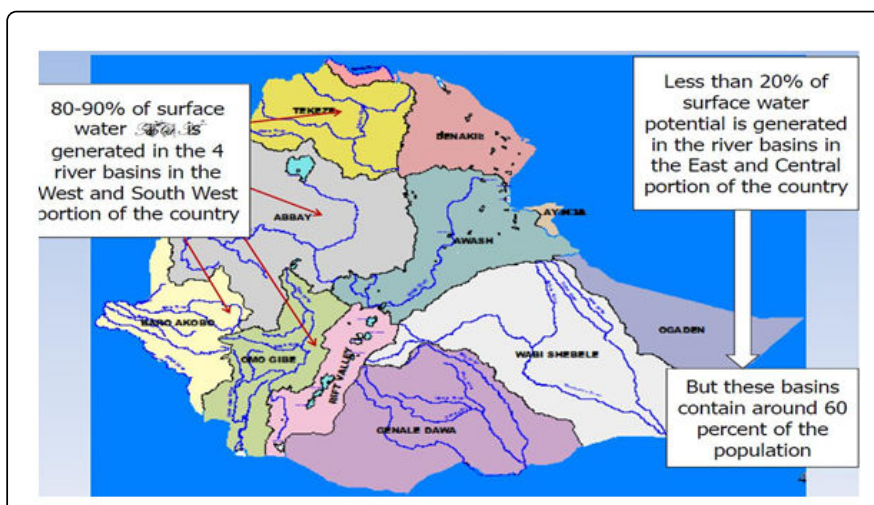

Figure 4: Uneven spatial distribution of major river basins.

\section{Technical challenges}

Ethiopia also faced by technical challenges to development of water resources. There are no well-equipped professionals in the areas of water infrastructure constructions, operation, maintenance etc. The country requires a wide variety of knowledgeable and skilled human power. On the other side, the country has variability in land features especially in topography, climatic conditions, and different natural resources like water. These variable conditions need different skilled expertise but there are no sandwiched professionals as well. The rain fall data are analysis by using models and rain fall-runoff methods. Only $40 \%$ of the country has metrological station, which is the data is analysis by using models and the remaining areas use rain fall runoff method. Whatever which method of analysis, both of them requires theoretically and technically equipped expertise to do it, but it is a great gap of the country to have an advanced professionals. The expertise who works in the rural areas is highly suffered by this issue due to have no access any skilled updated training and experience sharing [28]. 
Page 6 of 7

\section{Topographic features of the country}

Some major perennial rivers, for example Tekeze, of the country are flowing between steeply mountains which are not comfortable for living and irrigation (Figure 5).

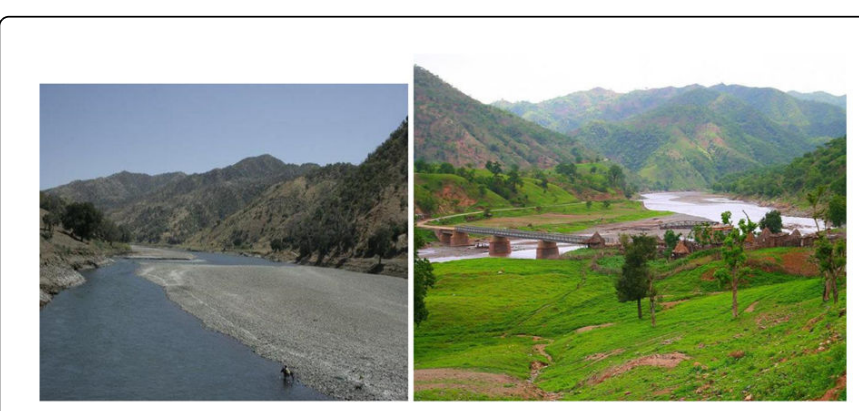

Figure 5: Perennial rivers.

\section{Economic challenges}

Ethiopia is developing country in Africa. The country has low capital income and this low capital income of the country leads give less focus and budget allocation to develop the water sectors. This is due to there are other areas which needs first consideration like hospitals, schools, educational sectors and others which requires a large amount of capital to construct and operate as well as to sustain their works. In the similar fashion, investments which are expend to expand water sectors especially for drinking water are not return its investment cost within a short period of time since the cost of water payment in the country is small when to compere the whole costs expend for construction. This is due to the fact the per capital income of the people of the country is very low so the government is mandated to support them to secure the safe drinking water accessibility with a small payment. Even those costs are not always sufficient for maintenance. For this reason small capital allocated for expansion of water resources developments is invested in few parts of the country mainly in the urban areas and the rural areas are always suffered a lot (Figure 6) [28].

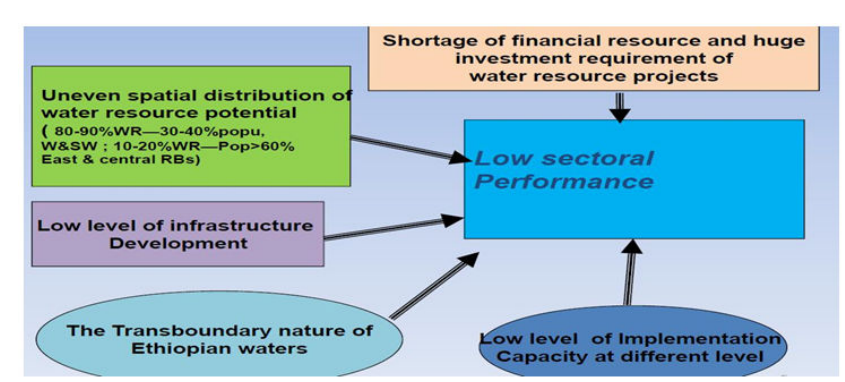

Figure 6: Summary of challenges in the development of the Ethiopian water sector [21]

\section{Recommended actions which shall give consideration}

- The government should give concerns for water resources development and utilization programs in every state and parts of the country.
- Find the source of additional fund from different funders and allocate sufficient budget to facilitate the task.

- Capacity building activities in all sectorial level shall encourage.

- Transboundary River management policy shall develop and put in place.

- Give consideration for climate change mitigation.

- Water harvesting technologies should expand in arid and semiarid areas in a special cause.

\section{Conclusion}

The water resources potential and its utilization rate are in comparable in the country. There are huge amounts of both surface and ground water resources but the utilization of it is in infant rate. It is clearly marked that the economic development of the country is never go far without utilization of water resources properly. But under current situation, the country is not used their water resources properly due to different political, natural, technical and economic factors. On the other side, the water sector development programs are performing well to increase the utilization potential and at the same time there are different eye opening future opportunities to develop the water resources development and utilization.

\section{References}

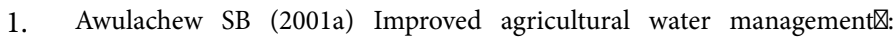
Assessment of constraints and opportunities for agricultural purposes. Improved Agricultural Water Management pp: 23-34.

2. MoWE (2013) Ministry of Water and Energy, FDRE.

3. Mohamed HY, Alamirew T, Melesse AM, Assen M (2013) Bathymetric study of Lake Hayq, Ethiopia. Lakes and Reservoirs: Research and Management 18: 155-165.

4. Awulachew SB (2010) Water-centered growth challenges, innovations and interventions in Ethiopia.

5. CSA (2007) Ethiopian population censes. Central Statistics Authority (CSA), Addis Ababa, Ethiopia.

6. Tadesse HS (2002) Engineers Proposal on how to Eradicate Hunger from Ethiopia. Highlights of Proposal Presented to Ethiopian Association of Civil Engineers, Berta Construction, Addis Ababa, Ethiopia.

7. Awulachew SB, Yilma AD, Loulseged M, Loiskandl W, Ayana M, et al. (2007) Water resources and irrigation development in Ethiopia. International Water Management Institute, Colombo p: 78.

8. MoWE and FAO (2012) Coping with water scarcity-The role of agriculture: Developing a water audit for Awash Basin, part 4: Water resources modelling. Ethiopia, GCP/INT/072/ITA.

9. FAO (1997) Irrigation potential in Africa: A basin approach, land and water division of FAO, FAO land and water bulletin 4, Rome, Italy.

10. Solomon SH (1998) Hydropower of Ethiopia: status, potential and prospects 1, ACS, 10th Annual Clinical Congress, Boston, MA, USA.

11. Halcrow MCE (2006) Awash Basin flood protection and watershed management project. Annex Wp3. Unpublished report, Addis Ababa, Ethiopia.

12. MoFED (2010) Plan for Accelerated and Sustained Development to End Poverty (PASDEP). Addis Ababa, Ethiopia.

13. Awulachew SB (2007) Abaya-Chamo lakes physical and water resources characteristics, including scenarios and impacts. Lake Abaya Research Symposium (LARS) 2007. University of Siegen and Arba Minch University 7th to 11th May 2007 Ethiopia.

14. Ayenew T, Robert B (2007) Comparative study of the hydrology and hydrogeology of selected Ethio-Kenyan Rift lakes. Lake Abaya Research Symposium (LARS) 2007. University of Siegen and Arba Minch University 7th to 11th May 2007, Ethiopia. 
Citation: Ayalew DW (2018) Theoretical and Empirical Review of Ethiopian Water Resource Potentials, Challenges and Future Development Opportunities. Int J Waste Resour 8: 353. doi:10.4172/2252-5211.1000353

Page 7 of 7

15. Dinka MO (2012) Analysing the extent (size and shape) of Lake Basaka expansion (Main Ethiopian Rift Valley) using remote sensing and GIS Lakes Reserv: Res Manag 17: 131-141.

16. Bernacsek GM, Hughes RH, Hughes JS (1992) A directory of African Wetlands. IUCN, Gland, Switzerland and Cambridge, UK/UNEP Nairobi, Kenya WCMC, Cambridge, UK.

17. Kebede S, TraviY, Alemayehu T, Marc V (2005) Water balance of Lake Tana and its sensitivity to fluctuations in rainfall, Blue Nile basin, Ethiopia. J Hydrol 316: 233-247.

18. Bird Life International (2013) Important bird areas factsheet: Lake Ashenge.

19. MoWR and GW-MATE (2011) Ethiopia: Strategic framework for managed groundwater development. Addis Ababa, Ethiopia.

20. Alemayehu T (2006) Groundwater occurrence in Ethiopia. Addis Ababa University Press, Addis Ababa pp: 1-105.

21. MoWR (Ministry of Water Resources) (2002) Ethiopian water sector strategy. MoWR, Addis Ababa, Ethiopia.

22. NMA (1996) Climatic and agroclimatic resources of Ethiopia, National meteorological services agency of Ethiopia. Meteorol Res Rep Ser 1: $1-137$.
23. Camberlin P (1997) Rainfall anomalies in the source region of the Nile and their connection with the Indian summer monsoon. J of Climate 10: 1380-1392.

24. Shanko D, Camberlin P (1998) The effects of the southwest Indian Ocean tropical cyclones on Ethiopian drought. Int J Climatol 18: 1373-1388.

25. Conway D (2000) The climate and hydrology of the Upper Blue Nile River. Geogr J 166: 49-62.

26. Seleshi Y, Zanke U (2004) Recent changes in rainfall and rainy days in Ethiopia. Int J Climatol 24: 973-983.

27. Awulachew SB (2001b) Water resources investigation and design guideline for potential exploitation in limited data situation: The case of Abaya-Chamo Basin (PhD Dissertation). Technical University, Dresden, Germany.

28. Berhanu B, Seleshi Y, Melesse AM (2014) Surface water and groundwater resources of Ethiopia: Potentials and challenges of water resources development surface water and groundwater resources of Ethiopia: Potentials and Challenges of Water. 